\title{
UNDERSTANDING THE GREAT \\ DEPRESSION: LESSONS FOR \\ CURRENT POLICY
}

Stephen G. Cecchetti

Working Paper 6015

\author{
NATIONAL BUREAU OF ECONOMIC RESEARCH \\ 1050 Massachusetts Avenue \\ Cambridge, MA 02138 \\ April 1997
}

This paper was prepared for the Western Michigan University 1996-97 Public Lecture-Seminar Series. I would like to thank Margaret Mary McConnell and Mark Wheeler for comments. This paper is part of NBER's research program in Monetary Economics. Any opinions expressed are those of the author and not those of the National Bureau of Economic Research.

(C) 1997 by Stephen G. Cecchetti. All rights reserved. Short sections of text, not to exceed two paragraphs, may be quoted without explicit permission provided that full credit, including $\mathbb{C}$ notice, is given to the source. 
Understanding the Great Depression: Lessons

for Current Policy

Stephen G. Cecchetti

NBER Working Paper No. 6015

April 1997

JEL Nos. E58, G28, N12

Monetary Economics

ABSTRACT

Over the four years beginning in the summer of 1929 , financial markets, labor markets and goods markets all virtually ceased to function. Throughout this, the government policymaking apparatus seemed helpless. Since the end of the Great Depression, macroeconomists have labored diligently in an effort to understand the circumstances that led to the wholesale collapse of the economy. What lessons can we draw from our study of these events?

In this essay, I argue that the Federal Reserve played a key role in nearly every policy failure during this period, and so the major lessons learned from the Great Depression concern the function of the central bank and the financial system. In my view, there is now a broad consensus supporting three conclusions. First, the collapse of the finance system could have been stopped if the central bank had properly understood its function as the lender of last resort. Second, deflation played an extremely important role deepening the Depression. And third, the gold standard, as a method for supporting a fixed exchange rate system, was disastrous.

Stephen G. Cecchetti

Department of Economics

The Ohio State University

Columbus, $\mathrm{OH} 43210$

and NBER

cecchetti.1@osu.edu 


\section{Introduction}

Macroeconomists continue to search for an understanding of the Great Depression of the 1930s. The defining characteristic of this period is the wholesale collapse of virtually every aspect of the economy. Over the four years beginning in the summer of 1929, financial markets and institutions, labor markets and international currency and goods markets all virtually ceased to function. Throughout this, the government policymaking apparatus seemed helpless. The complexity and magnitude of the economic catastrophe during this period make it extremely difficult to fashion a comprehensive explanation.

Over the nearly sixty-five years since the cyclical trough in March 1933, researchers have churned out volumes of work analyzing the forty-three month contraction. Since 1969 alone, EconLit, the CD-ROM index compiled by the Journal of Economic: Literature, lists over 400 articles on the 'Great Depression.' Where has all of this work gotten us? What have we learned over the past quarter century that can help us as we go forward?

One of the things we know is that our economic institutions are very different today than they were in 1929. Many of the changes are surely the result of the Depression itself. A few of the more important things that clearly came out of this period are that the Federal Reserve System is more centralized, we have deposit insurance and stronger bank regulation, commercial and investment banking are separated (at least for now), we have a pure paper money standard, and we have unemployment insurance and social security.

Have these changes worked in helping us to avert the onset of another Great Depression? Clearly, the past fifty years have been characterized by a substantially more stable economic environment. Since 1945, the longest, from November 1973 to March 1975, lasted a mere sixteen months - just over one-third the length of the Depression. The largest sustained drop in output has been a $2.1 \%$ change in the early 1980 s, compared with the decline of nearly $30 \%$ in the early 1930 s. While consumer prices fell 28\% from August 1929 to April 1933, in no year since 1949 has 
the CPI shown a decline. In December of 1982 , the civilian unemployment rate hit its post-WWII peak of 10.8 percent, while the estimate of the 1933 peak exceeds $25 \%$ !

Financial markets and institutions have fared equally well in the stable environment of the post-World War II economy. From its peak in mid-September of 1929 to its trough in late June 1932 , the return on a broad index of large company stocks (equivalent to the Standard and Poor's 500) fell by $86 \%$. By comparison, the largest sustained drop in the past 50 years is the decline of $52 \%$ from mid-January 1973 to early October 1974.

The total collapse of the financial intermediation system was signaled by the fact that from the beginning of 1930 to the bank holiday of 1933, there were an astounding 9096 commercial bank suspensions! The 1350 in 1930 alone was more the double the 659 in 1929. By contrast, in the sixty years since 1934 there have been a total of just over 2000 bank closings.

International goods markets broke down as well. From 1929 to 1932, exports fell from $6.8 \%$ to $4.5 \%$ of gross output. In the fifty years since the end of WWII, exports of goods and services have grown from $3.5 \%$ of gross national product to nearly $12 \%$.

International financial markets suffered as well during the Great Depression, with the gradual break down of the fixed-exchange rate system administered through the gold-exchange standard. Slowly, over the decade of the 1930s, all of the countries that had been on the reconstructed, post-World War I gold standard, left it. The desire to have a fixed-exchange rate system has obviously been very strong, as this was followed by the Bretton Woods system, and then the European Monetary System.

Analyzing all of these events in any detail is clearly too big a task to undertake in one short essay. Instead, my goal is to point out what I think are the highlights. My presentation is split, into four basic sections. Each begins with what I believe to be one of the major fallacies contained in the literature on Great Depression. My purpose is to examine what truth lies behind each of these to see what lessons we can learn. I come away with three important lessons that have become my own personal guide to policy analysis. 
The four fallacies are as follows:

1. The Great Depression was caused by the stock market crash of 1929 .

2. The banking system of the 1920s was fundamentally unsound.

3. The fact that nominal interest rates were approaching zero meant that Federal Reserve policy was loose and ineffective.

4. Tariffs wars were primarily responsible for the spread and depth of the Depression.

I will argue that, from these come the following lessons for current policy:

1. The central bank's function as the lender of last resort is of primary importance in the short-term stabilization of the financial system.

2. Deflation is extremely costly.

3. A gold standard is very dangerous.

Finally, I will comment on remaining mysteries. There are two important aspects of the Depression that we still do not fully understand. First, why was it so long? Second, what is the comprehensive explanation for the entire inter-war period?

\section{The Stock Market Crash of 1929}

The crash of October 1929 has played a large role in the lore of the Great Depression. Over time, however, a number of issues have become clear, and we are now understand the likely causes of the crash, and its likely consequences.

Let me begin with myths about the causes. In a recent essay, Cecchetti (1992b), I argue that there is very little evidence for the three most commonly believed reasons that asset prices feel so precipitously: (1) the bursting of a speculative bubble, (2) massive fraud and illegal activity and (3) margin buying. Regarding the first, I note 
that, as Dominguez, Fair and Shapiro (1988) demonstrate, contemporary data did not reveal any trends that suggested the drastic downturn that followed. Furthermore, it is easy to find quotes from contemporary analysts supporting both the position that the market would rise, and the position that the market would fall. In other words, economic fundamentals were also sound in late 1929.

There are numerous anecdotes that leave one feeling that fraud and illegal activity are an important explanation. ${ }^{1}$ But Bierman (1991) has carefully examined the evidence and shows that there was probably very little actual insider trading or illegal manipulation. Instead, a number of lucky and unlucky investors were pilloried for perfectly legal actions.

The best evidence we have is that the crash was caused by Federal Reserve behavior, together with the public statements of numerous government officials. It has been amply documented, initially by Friedman and Schwartz (1963) and more recently by Hamilton (1987) and others, that Federal Reserve policy became substantially tighter in the fall of 1928, almost immediately following the death of Benjamin Strong, the President of the Federal Reserve Bank of New York. While he was alive, Strong controlled Federal Reserve policy, as the Federal Reserve Board was not as powerful as it is today. But when Strong died, Adolph Miller of the Federal Reserve Board was able to take control of policy. Miller believed that speculation was causing share prices to be too high, and that this was damaging the economy. Together with Herbert Hoover, who had just been elected President, he set out to bring down the stock market.

In its attempt to bring equity prices down, the Federal Reserve sought to keep banks from extending loans that would be used to buy stock. To this end, the February 1929 Federal Reserve Bulletin contained the following policy statement, taken from a February 2, 1929 letter sent to Federal Reserve banks.

During the last year or more, however, the functioning of the Federal reserve system has encountered interference by reason of the excessive amount of the country's credit absorbed in speculative security loans. The

\footnotetext{
${ }^{1}$ This is surely the conclision that would be drawn by a reader of Galbraith (1954).
} 
credit situation since the opening of the new year indicates that some of the factors which occasioned untoward developments during the year 1928 are still at work. The volume of speculative credits is still growing....

The extraordinary absorption of funds in speculative security loans, which has characterized the credit movement during the past year or more, in the judgment of the Federal Reserve Board, deserves particular attention lest it become a decisive factor working toward a still further firming of money rates to the prejudice of the country's commercial interests....

The Federal Reserve Act does not, in the opinion of the Federal Reserve Board, contemplate the use of the resources of the Federal reserve banks for the creation or extension of speculative credit. A member bank is not within its reasonable claims for rediscount facilities at its Federal reserve bank when it borrows either for the purpose of making speculative loans or for the purpose of maintaining speculative loans.

The board has no disposition to assume authority to interfere with the loan practices of member banks so long as they do not involve the Federal reserve banks. It has, however, a grave responsibility whenever there is evidence that member banks are maintaining speculative security loans with the aid of Federal reserve credit. When such is the case the Federal reserve bank becomes either a contributing or a sustaining factor in the current volume of speculative security credit. This is not in harmony with the intent of the Federal Reserve Act, nor is it conducive to the wholesome operation of the banking and credit system of the country. (Board of Governors of the Federal Reserve 1929:93-94)

(It is worth noting that the term 'speculation' appears to have been common usage for share purchases that were made with borrowed money.)

I will simply note that this passages suggests the central bankers did not understand the difference between transactions that represent portfolio reallocations and those that used real resources. An example will help to make the point. Consider 
a case in which a person holding an equity share wishes to sell it and purchase a bond. Another person wishes to purchase the share, and incur debt (issue a bond). For simplicity, say that the seller is willing to accept the bond issued by the buyer in payment. Such a transaction is essentially a risk trade, and results in a net increase in the gross quantity of debt outstanding with no change in the level of equity, or anyone's net worth. The portfolio's of the two people do change as one individual goes from holding equity to holding debt, and the other goes from have no assets and liabilities to having an equity asset and a bond liability.

The passage from the Federal Reserve Bulletin clearly shows that the Federal Reserve Board thought that the increase in debt somehow used real resources, and reduced the level of real investment. While confusion between real and financial investment is common in the popular press, we can rightly expect more from those people who are in charge of policymaking.

It is no surprise that following the Federal Reserve Board's pronouncement, the interest rate charged on broker loans rose dramatically. In fact, this action very nearly generated a crash on March 26, 1929. On that day, call money rates opened at 12 percent, and rose to 20 percent by noon. Meanwhile, stock prices fell by nearly 10 percent. But action by both the Federal Reserve Bank of New York and the First National Bank to provide liquidity to the market in the form of broker loans stemmed the decline, and prices recovered almost entirely by the close of the day. Both Charles E. Mitchell, President of First National Bank, and George Harrison, President of the Federal Reserve Bank of New York, were later criticized for taking these actions. In many ways, these attempts at expansion of liquidity and the associated criticisms were a precursor of things to come.

Even after the near crash in March, Federal Reserve policy continued to stifle the market by restricting the ability of member banks to make broker loans. This policy of 'direct action', whereby the Federal Reserve openly discouraged lending collaterized by stock, did have the effect of stemming the increase in broker loans that originated from banks. In fact, broker loans from New York banks fell between March and May 
of 1929 .

A second important contributor to the crash was likely to have been the repeated statements by public officials that stock prices were too high. The main culprit here is President Herbert Hoover, whose public comments supported Adolph Miller's attack on speculation.

We do not know why the market crashed exactly when it did. But it is clear that the actions of the Federal Reserve were very different in October that they were in March. After many months of warning, banks were not willing to extend broker loans to stem the decline, and the Federal Reserve had no desire to provide the liquidity that would have been necessary for the banks to do so. As a result, once the market became disorderly and prices began to plummet, matters simply became worse.

This story suggests that the Federal Reserve could have stopped the stock market from crashing. The reason they did not is that Adolph Miller and his colleagues believed that credit extended to brokers for loans to purchase securities was, in some sense, credit that was unavailable to the commercial sector, and so raised interest. rates and harmed business activity generally. This position is very difficult to justify, particularly since Federal Reserve accommodation could have simply increased total credit outstanding in order to keep interest rates on commercial loans at a level that was considered desirable. Furthermore, there is evidence that Benjamin Strong understood in 1928 that the solution to high interest rates was looser policy, not artificial attempts to reduce broker loans.

The consequences of the crash are more difficult to ascertain. The explanations just cited follow Friedman and Schwartz in viewing the crash as a by-product of the tight Federal Reserve policy, and ignoring any direct effect of the crash on economic activity. But there are at least four ways in which the stock market decline could have influenced consumer spending, and therefore output. First, the crash could have depressed consumer spending by leading people to believe that the Depression was coming. The work of Dominguez, Fair and Shapiro (1988) suggests that this is unlikely. Second, the market crash reduced wealth, and this could have reduced con- 
sumer spending. But this is unlikely to have a large effect, given that the stock market remained above its level at the beginning of 1928 throughout 1929. Mishkin (1978) argues that the crash, together with recently accumulated consumer debt, served to make households illiquid. He then estimates that roughly two-thirds of the fall in spending can be accounted for by the deterioration of household balance sheets.

Finally, Romer (1990) argues that the stock market crash created immediate income uncertainty resulting in a decline in the purchase of consumer durables, for which she provides substantial empirical support. Specifically, Romer shows that there was a dramatic decline in new automobile registrations and department store sales immediately in November 1929. Mail-order sales began to fall in January 1930. This evidence suggests that some of the blame for the contraction can be traced directly to the stock market crash of 1929 and substantiates certain aspects of Temin's (1976) original hypothesis that the initial contraction in output in 1929 resulted from a collapse of consumption expenditure. Romer's position is bolstered by evidence in Cecchetti and Karras (1994), who find that there was a very large aggregate demand shock of nonmonetary origin in November 1929 that is largely responsible for the downturn of 1930 .

There are two important lessons to be taken away from this experience. Both concern the behavior of central bankers. First, I believe that if central bankers allow the fluctuations in asset market prices to affect their decisions it may distract them from concentrating on some combination of output growth and inflation. The focus of the Federal Reserve on the level of equity prices in 1929 clearly led to a disastrously contractionary path for policy.

Second, the central bank can operate effectively as a lender of last resort only if it stands ready ready to provide immediate liquidity to any bank that presents assets meeting certain predetermined criteria. That is to say, if the financial system is comes under stress, as it surely will during a sudden downturn in equity prices, the Federal Reserve can attentuate the impact on the economy if it stands ready to supply reserves to the banking system. Again, the evidence suggests that, in October 
1929, the Federal Reserve's actions severed to exacerbate the problems caused by the crash.

\section{The Importance of Sound Financial Intermedi- aries}

\section{The Financial Crises of the 1930s}

The failure of the system of financial intermediation culminating in to the bank holiday of 1934 strongly suggests that there was something inherently wrong with the organization of the banking system prior to the Depression. Why did the banking system collapse? Was the net worth of banks too low? There is a simple prima facia case that we can make against such a singgestion. First, there is the fact that banks entered the Depression with what, by modern standards, were very high amounts of equity. Looking at book valıe bank balance sheets, at the end of 1929, bank capital was $14 \%$ of assets. By 1940, it had fallen to $9 \%$. While it has risen to over $7 \%$ recently, for most of the 1980 s, capital was less than $6 \%$ of assets.

But these are accounting numbers, and they may not be representative of the truc economic condition of banks. If we had been able to compute the market value of bank assets, would they have been less than the value of bank liabilities? As has been emphasized in the banking literature, banks are maturity transformers. They take short-term liabilities and turn them into long-term assets. Since these assets are often not marketable, there is substantial risk involved in such a transition. The main risk comes from nominal interest rate movements. As nominal interest rates rise, the revenue stream from banks' long-term assets may be insufficient to service the obligations created by their short-term liabilities.

Were nominal interest rates rising during this period? Would one expect this to be a problem? The answer, which we can obtain from Cecchetti (1988b), is clearly no. The data in Figure 1 clearly show that nominal interest rates fell throughout the 
Table 1: Chronology of Monetary Events During the Depression from Friedman and Schwartz (1963)

\begin{tabular}{l}
\hline 1 - October 1929 - Stock Market Crash \\
2 - October 1930 - First Banking Crisis \\
3 - March 1931 - Second Bank Crisis \\
4 - September 1931 - Britain Leaves the Gold Standard \\
5 - January 1933 - Last Banking Crisis \\
6 - March 1933 - Bank Holiday \\
Numbers correspond to vertical lines in the Figures.
\end{tabular}

Figure 1: Nominal Interest Rates: 3 Month \& 5 Year Yields Monthly 1929 to 1940

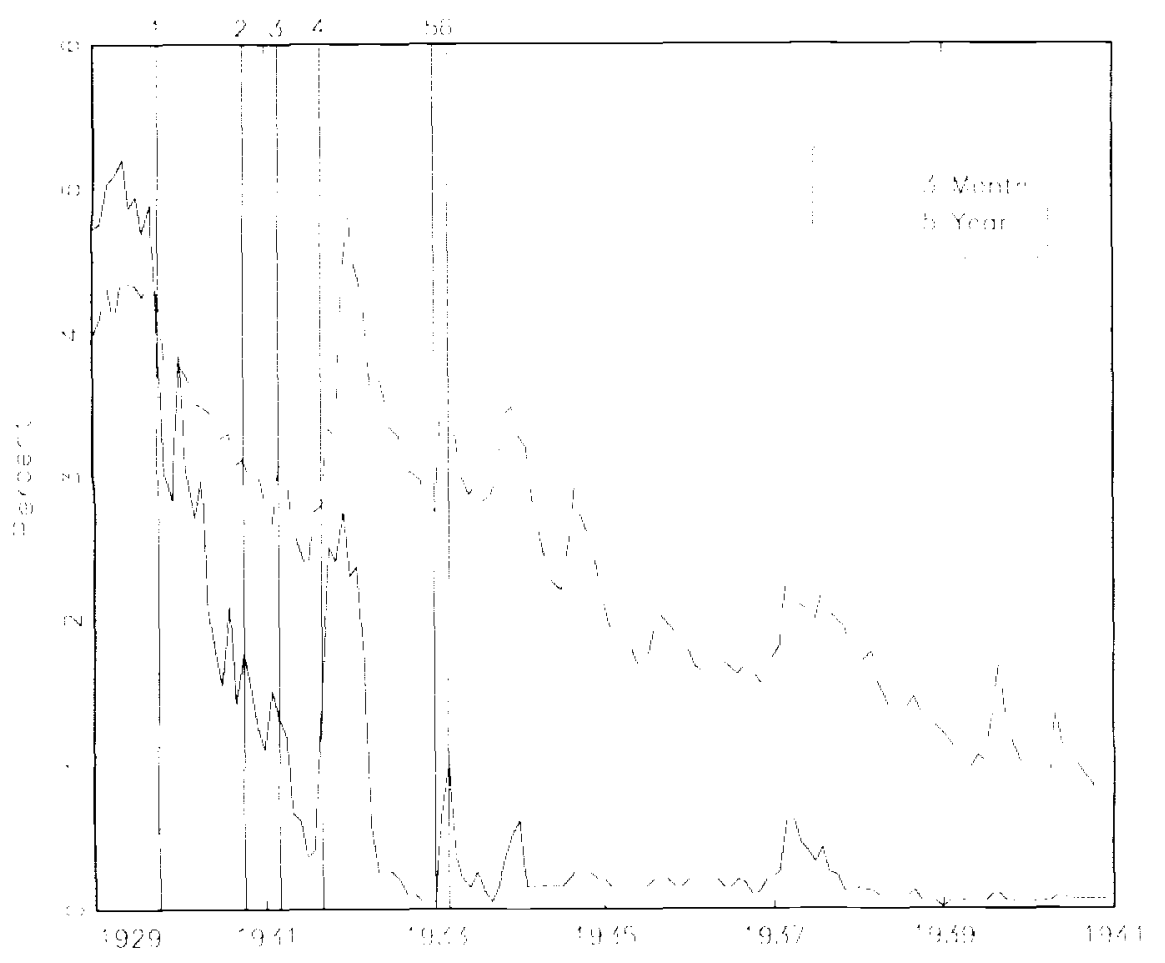


Depression. Three month U.S. government rates fell from just over 5 percent in the spring of 1929 to less than one-half of one percent by July 1931. While they went up significantly for a few months in late 1931, around the time when Britain left the gold standard, they quickly returned to very low levels and remained there until after World War II. Long-term interest rates followed a similar pattern. Falling through most of 1929, 1930 and most of 1931.

An alternative explanation for the banking system collapse is the debt-deflation hypothesis. First advanced in Irving Fisher's (1933) original 1933 paper, and more recently formalized by Ben Bernanke and Mark Gertler (1989 and 1990), the theory is that the $30 \%$ cumulative deflation of 1930-32 was primarily responsible for the depth of the Depression. The argument proceeds as follows. Since manticipated deflation increases the real burden of nominal debt, it caused debtors to default on loans, which led to bank failures and the collapse of the financial system. Bernanke and Gertler (1989 and 1990) examine a formal model in which deflation lowers borrower net worth, thereby increasing leverage and the desire of entrepreneurs to take on risk. This raises the probability of bankruptcy, lowers the level of investment, and causes a reduction in both aggregate supply and aggregate demand.

Once again, the problem can be traced to behavior of the Federal Reserve. Without the deflation, the financial system would not have disintegrated. Since the deflation is clearly a monetary phenomena, we have found the villain.

Unfortunately, we should not stop here. We must look further, as the banking system crashed in a series of systemic panics. These waves were surely unnecessary. Their defining characteristic was that solvent banks were forced into bankruptcy as depositors demanded convertibility of their deposits into currency, and all the banks had were non-marketable assets.

Was there a policy failure here as well? The consensus is that there was. The job of the lender of last resort is to step in at exactly these times. Why was the Federal Reserve so reticent to engage in making discount loans during this period? Figure 2 shows the path of discount loans during the interwar period. The most striking feature 
Figure 2: Federal Reserve System Discount Loans

Monthly 1919 to 1934

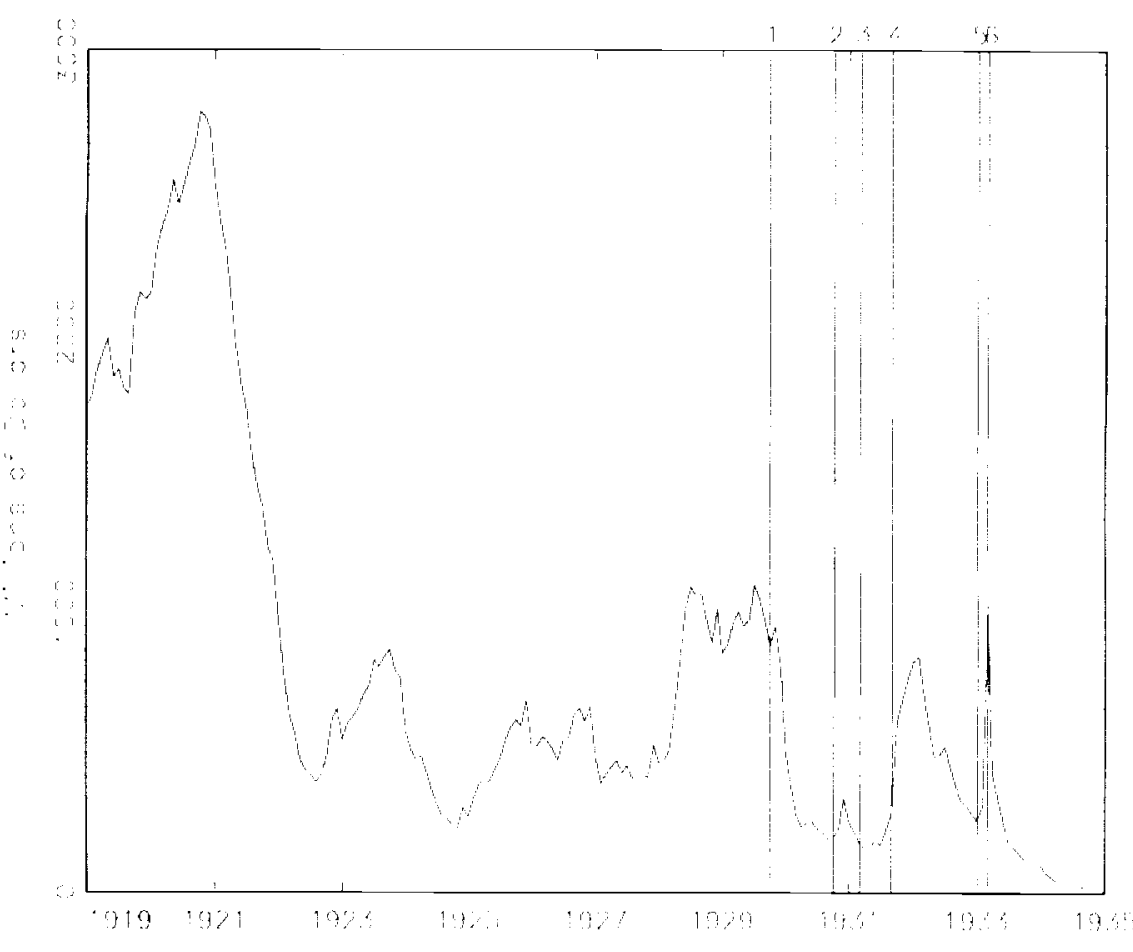

of this figure is that during the 1920-22 deflation, Federal Reserve lending increased substantially, hitting its peak just prior to the trough of the business cycle. ${ }^{2}$ This is in stark contrast to the pattern during the initial phases of the Depression. Beginning with the crash and ending in late 1931, well after the second banking crisis, the level of borrowings fell and stayed at a very low level.

Data on bank suspensions show that from 1930 to 1932 an average of 1,699 banks, representing an average of over $\$ 1$ billion in deposits, suspended operation each year. Assuming that the volume of loan defaults is roughly proportional to the level of suspended deposits, one can infer that as banks were becoming illiquid in 1930, Fed lending was declining.

In light of the deterioration of bank assets during the early 1930's, it seems extremely unlikely that the decline in borrowing from the Fed resulted solely from

\footnotetext{
${ }^{2}$ The increase in borrowing came about despite the increase in the discount rate from 4 to 7 pereent.
} 
demand side factors. ${ }^{3}$ Instead, it seems plausible to assume that the Fed played some role. The Fed's failure to actively encourage borrowing to meet the short-run liquidity demands of depositor should not be overlooked. In essence, the Fed failed to perform as the lender of last resort. Without an ultimate source of short-run cash, banks were forced to suspend operation. If, on the other hand, the Fed had actively sought to discount bank assets, the bank panics could have been averted and the deflation would not have been as prolonged.

\section{Institutional Responses}

The solutions offered during the 1930s had three major components. They were the provision of added information to potential investors, the creation of deposit insurance, and the fragmentation of the financial system. The last of these has now largely been undone. The first has been, and I hope will continue to be, emphasized. But, what should we make of deposit insurance? The purpose of deposit insurance is to eliminate systemic bank runs. Surely, it has worked.

But deposit insurance creates incentive problems for banks, since depositors do not have any interest at all in the quality of bank assets. Bankers are, in essence, able to gamble with government guaranteed funds. This leads to powerful arguments against deposit insurance. The alternative, implicitly advocated by these critics, is that the lender of last resort will function to keep solvent banks from folding and allow insolvent once to close. The problem with such a strategy is that it requires that the lender of last resort be cuick and nimble in its reactions. My sense is that we are better off relying on imperfect institutions that offer automatic responses than central bankers, who many not realize what is needed.

\footnotetext{
${ }^{3}$ From December 1929 to June 1933, total assets of Federal Rescrve System member banks foll stcadily from $\$ 48.1$ billion to $\$ 33.0$ billion.
} 
Figure 3: Consumer Price Inflation, 1919-1940

Twelve Month Changes

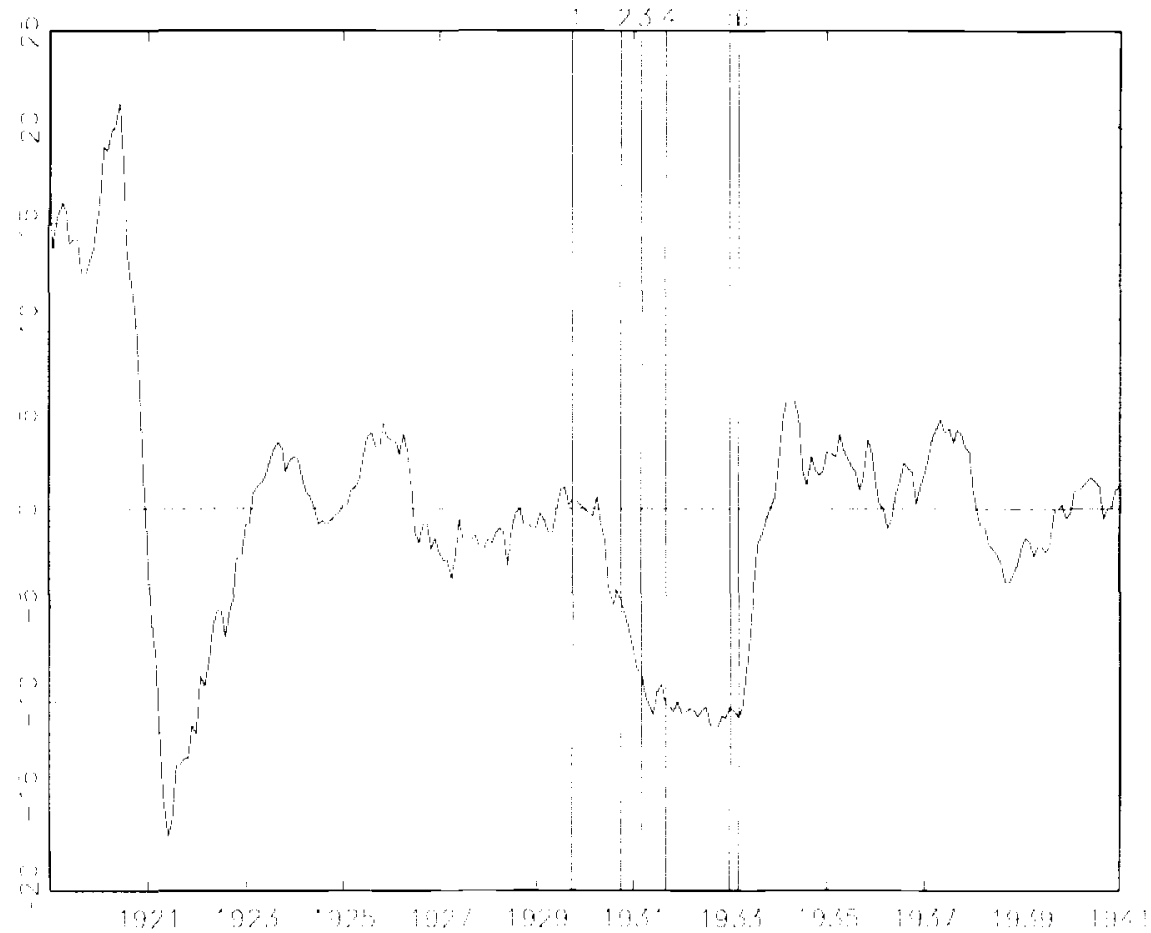

\section{Understanding the Effects of Deflation}

Past discussions of the Depression have at times been muddled by the fact that nominal interest, rates were extremely low during the entire period. Once the three month U.S. Treasury Bill rate fell below 3 percent in 1930, it did not rise back to this level until after World War II. In fact, as Figure 1 shows, by modern standards the nominal interest rate was remarkable low over the entire period from 1929 to 1940.

This fact caused a particularly simple type of confusion. It was thought by some that since nominal interest rates were low, Federal Reserve policy must not be contractionary, and so it could not be responsible for the Depression. How, people thought, could monetary expansion have been efficacious in this circumstance, when the nominal interest rate was already so low? This argument led to theories of a so-called liquidity trap - the notion that there is some point at which further changes in the quantity of money have no impact on the interest rate.

This line of reasoning confuses nominal and real interest rates. During the early 
Figure 4: Ex Ante Real Interest Rate, 1919-1940

Monthly at an Annual Rate, Three-Month Horizon

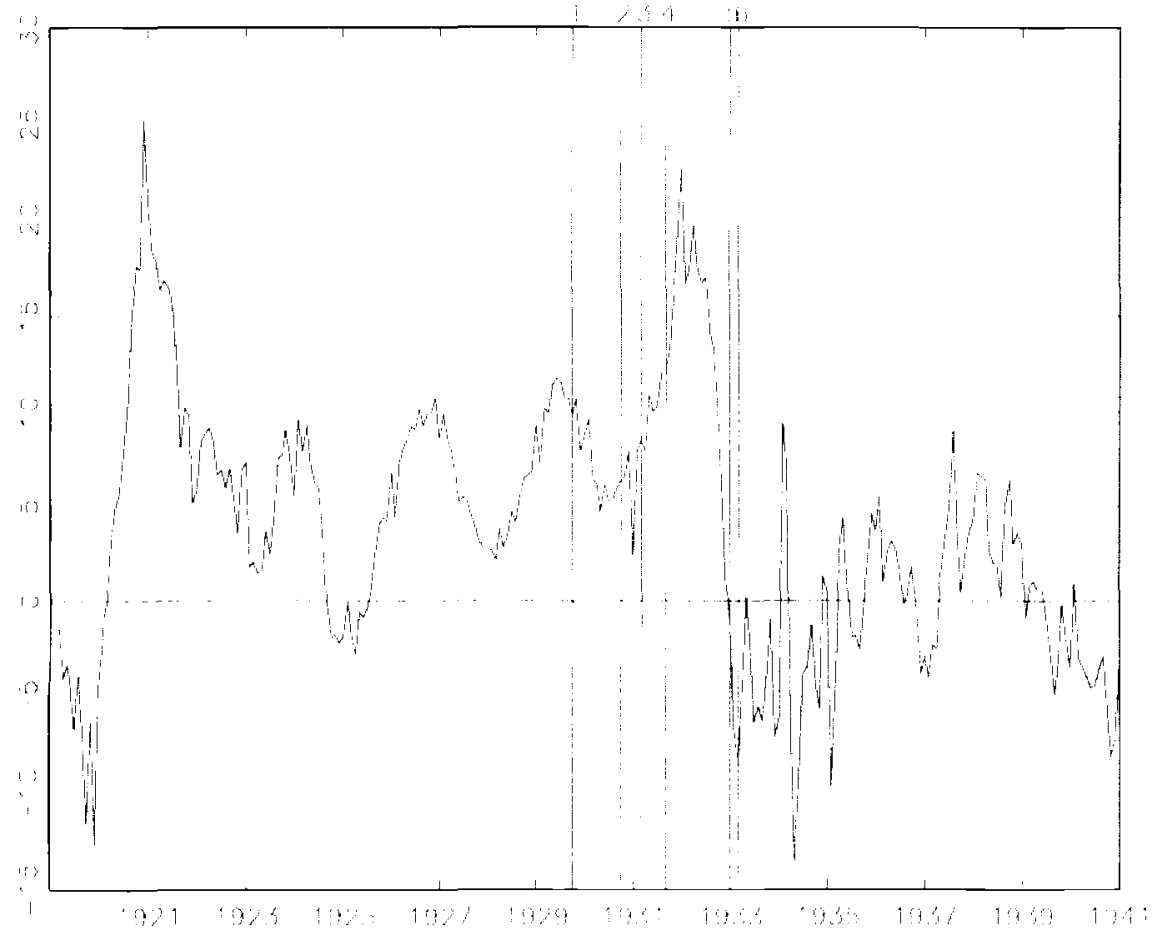

1930 s, there was a tremendous deflation. Over a three year period, consumer prices fell by nearly $30 \%$. Figure 3 shows the pattern of inflation for the entire interwar period. The main points to note are that there were two large deflations. In addition to the 1930 s, there was the 1920-22 deflation in which consumer prices fell by approximately $18 \%$.

When people expect prices to keep falling, ex ante real interest rates will be very high. To see exactly how high they might have been during the Depression, in Cecchetti (1992b) I estimated real interest rate for three month loans. The results are reported in Figure 4. The most important thing to realize about these is that the real interest rate during the entire Depression period was extremely high - the peak in early 1932 exceeded 20 percent! This is high by any standard. At no point since the end of the Depression have real interest rates exceeded even 10 percent. So, while nominal interest rates were low, real interest rates were very, very high.

The clear cause of these high real interest rates was extraordinarily tight policy. 
As was first emphasized by Friedman and Schwartz (1963) and has been discussed by many others since, the monetary aggregates were shrinking quickly over this period. For example, M1 went from a high of $\$ 26.7$ million at the August. 1929 cyclical peak to $\$ 19.5$ million at the April 1933 cyclical trough, a drop of 27 percent. M2 followed the same pattern, declining by one-third over the same nearly four year period. The Federal Reserve's confusion, of course, came from the fact that this was all going on at the same time that they were actively expanding the monetary base. Clearly, policymakers did not take account of declines in the money multiplier -- the ratio of broad measures of money such as M2 to the monetary base - when they were evaluating their policy stance.

Once again, the debt-deflation hypothesis is the widely accepted explanation for how central bank policy created such a disaster. But the theory requires that deflation be unanticipated. There is some debate over whether the deflation was actually unanticipated [see Cecchetti (1992a), Hamilton (1992), and Nelson (1991)]. If not, then theories that rely on high ex ante real interest rates, and the resulting collapse of consumption and investment, might be more relevant than the debt-deflation hypothesis. ${ }^{4}$

A complementary explanation is that temporary deflation led to high real interest rates, which in turn caused the decapitalization of the economy. Such a theory can be constructed from a model used by Calvo (1985 and 1986) to study anticipated temporary changes in money growth. While his original purpose was to study the impact of disinflation programs in Central and South America, his results can be used here as well.

If one accepts that the deflation of 1930 32 was (at least partially) anticipated, but expected to be temporary, then it is possible to study the behavior of consumption and capital accumulation using a monetary version of Calvo's (1985 and 1986) model. When the money growth rate declines, depending on whether the ensuing deflation

\footnotetext{
${ }^{4}$ Examples of these competing theories wan be found in the simple IS-LM theory of Gorclon and Wilcox (1981) and the classical theory in Cechetti (1988a).
} 
is severe enough to cause the nominal interest rate to hit its lower bound, two things can happen. ${ }^{5}$

If the money growth rate is negative, but the opportunity cost of money remains positive, then the impact of the policy is straight forward. Consumption jumps up and then declines throughout the temporary policy period. At the same time, the capital stock falls and then begins to rise slowly. The reason for the transitory rise in consumption is that the effective cost of consumption is expected to rise in the future. The severity of the consumption and investment collapse depends on both the size of the money growth decline and the length of time it is in place. The larger the fall in the money growth rate, the more severe the declines. On the other hand, increases in the length of time for which the policy is in place can be either good or bad. If the policy were in effect for either zero or infinite time, there would be no change in consumption or the capital stock - the model is superneutral. This implies that there is some finite value for the time that the money growth rate is at its low level which maximizes the fall in consimption and the capital stock. The impact is less severe if the policy is in place for either a longer or shorter time.

In the second case, where the opportunity cost of holding money becomes negative, the consumption and investment declines are potentially much larger. When cash, or other government issued liquid assets, provide a real rate of return above that available on any physical investment, agents will attempt to move their assets into cash. The nature of money is completely changed. This simultaneonsly drives down the value of the in-place capital stock and results in negative net investment. In essence, the economy is decapitalized. The decapitalization is accompanied by a decline in consumption. The consequences are clearly catastrophic. Not only does the value of the in-place capital decline, but the demand for firms' production falls

\footnotetext{
${ }^{5}$ This lower bound is difficult to determine. One would expect that it restriets the nominal interest rate to be nonnegative. If this were true, the short term interest rates plotted in Figure 4 wonld lead one to conclucle that this is an irrelevant case for the 193032 period. But in stuelying this period, it is important to keep in mind the existence of postal savings accounts. These effectively increased the nominal interest rate floor for individuals to the legislated $2 \%$ rate paid by the U.S. Government.
} 
as well. This in turn decreases their ability to repay loans, making bank deposits less safe. The deterioration of the quality of bank assets drives individuals to hold cash.

The main lesson here is clear. Deflations, even expected ones, are very damaging. The fact the nominal interest rate has a natural lower bound, means that deflation can lead to increases in real interest rates that are extremely damaging. For recent discussions of inflation targeting, the message is to beware of targets that imply a significant chance of deflation. It therefore may be dangerous to target zero inflation.

\section{International Aspects of the Depression}

The Great Depression was a world-wide phenomenon, affecting virtually all of the industrialized countries. The pervasiveness of the economic collapse has led to a study of the manner in which aggregate fluctuations are transmitted across economies. Both financial and goods market transactions link the international system. What part did each of these play in the global collapse and what are the important lessons we have learned about exchange rate systems and international trade? The remainder of this short section discusses each of these. I begin with a description of the gold standard, followed a short discussion of the tariff system.

\subsection{The Gold Standard}

In the last decade we have made great strides in our understanding the role of the gold standard in the propagation of the Depression. Numerous people contributed to this understanding, beginning with Choudhri and Kochin (1980), followed by Hamilton (1988), Temin (1989) and Bernanke (1995). But it is Eichengreen (1992) who is responsible for consolidating the improvement in our knowledge. ${ }^{6}$

The gold standard of the interwar period was a fixed-exchange rate system, whereby the central banks in all of the major countries of the world all stood ready to exchange

\footnotetext{
${ }^{6}$ See Bernanke's (1993) review of Eichengreen's book and his 1995 Money, Credit and Banking Lecture for concise summaries of Eichengren's argument.
} 
their currency for gold at a fixed rate. The purpose of the system was to stabilize economies through specie flows. If one country's economy began to shrink, it's aggregate price level would begin to fall. At the fixed gold-currency exchange, it would then be profitable to import gold into the affected country. This would increase the stock of money, and provide a stabilizing force.

It is important not to confuse this international institutional arrangement with contemporary calls for the institution of a domestic gold standard. For one country to adopt a gold standard in isolation would be to fix the currency price of gold. The result would be that all fluctuations in the relative price of gold, for whatever reason, would have to be absorbed by the general price level. For example, if an increase in political instability somewhere in the world were to drive up the demand for gold, instead of the currency price of gold rising, the aggregate price level would have to fall. Needless to say, given the fluctuations in the real price of gold since the collapse of Bretton-Woods twenty-five years ago, this would create incredible instability.

The gold standard of the interwar period is more correctly referred to as a goldexchange standard, and, as mentioned above, its primary purpose was to establish and maintain a system of fixed exchange rates. While central banks were required to hold reserves to back their monetary base, those reserves could be part monetary gold and part foreign exchange. Furthermore, requirements generally stated that the central bank need only hold 30 to $40 \%$ of the value of the monetary base as backing. The real problem comes with the fact that countries losing gold (e.g. because they were running current account deficits) had no choice but to contract their money stocks. But countries gaining reserves could choose whether to sterilize the inflows, leaving their money stocks unchanged, or allow their monetary base and money stock to grow.

The U.S. and France were the major surplus countries during this period, and so they were beneficiaries of gold inflows. But, both of these countries sterilized the inflows, forcing the world money stock to decline substantially and rapidly. Once again, we come to the conclusion that the Federal Reserve's contractionary policy, 
beginning in 1928, is of the utmost importance in understanding the nature of the Depression. ${ }^{7}$

The most persuasive case for the causal role of the gold standard comes from Bernanke and James (1991) and Bernanke (1995). They show that the depth of the Depression depended critically on when a country left the gold standard. Those countries that left earliest, such as Great Britain (1931), had shallower contractions that the U.S. (1933) and France (1936).

It seems likely that we have learned the most important lesson that comes from this experience. Namely, that the international transmission of shocks depends on the exchange-rate regime. Fixed exchange rates allow transmission of certain types of shocks that are buffered by the movements in flexible exchange rates. In particular, in a fixed exchange rate system, central bank policy is unable to buffer disturbances to the real economy - in effect, one looses control of the size of one's money stock. Without coordination of central bank policies among central banks, a fixed-exchange rate block is not viable.

The European Monetary Union is an obvious response to this. European countries have decided to institutionalize fixed exchange rates and coordinated policy by actually eliminating both individual currencies and autonomous central banks. Such a setup will surely eliminate the possibility of the calamitous events of the $1930 \mathrm{~s}$.

\subsection{Tariffs}

A commonly held view is that the tariff wars of the 1930s bore significant responsibility for the wholesale collapse of economic activity. For example, Meltzer (1976) has argued that the Smoot-Hawley tariff, instituted in June 1930, was of paramount importance in deepening the world-wide depression.

This view has been challenged by Crucini (1994). Crucini notes that most import

\footnotetext{
${ }^{7}$ I ann leaving ont mumerous cletails about the mechanics of the gold-exchange standard and its impact. For example, the sequence of bank panics led central banks to reduce their foreign exchange holdings, forcing them to further contract their money stocks.
} 
duties were specific, not ad valorem. This means that they were stated in fixed dollar amounts per unit of import. As a result, the main fluctuations in the real value of the tariffs came not with legislated changes in the tariff rates themselves, but with movements in the aggregate price level. Once again, it is the deflation during the 1930s that is the villain, raising tariffs by much more than even the Smoot-Hawley tariff.

But this point begs the question of the impact of the tariff changes. Crucini and Kahn (1996) examine the macroeconomic impact of these changes. They note that by raising real tariff rates, contractionary central bank policy could have a quantitatively important impact on output. But while their findings are large by comparison with what one might expect, they are at most ten percent of the peak-to-trough decline in output, or something like a cumulative 3 percent decline.

\section{Lessons and Remaining Mysteries}

Our collective efforts at understanding the Great Depression have yielded a number of important lessons for current policy. These fall into two broad categories: lessons for policymakers and those for about the construction of financial institutions. The experience of the Depression teaches central bankers both about the dangers of deflation and about the proper operation of the lender of last resort.

Regardless of whether it is anticipated or not, deflation clearly devastates an economy. Extreme aversion to deflation has a number of important implications for current policymakers. First, and foremost, it suggests that setting a target of zero inflation for central bank policy may dangerous. One must assume that, with a competent policymaker in control, there is an equal chance that resulting inflation will be above or below the targeted level. But if deflation is a bad outcome, there should be an extreme aversion to it, and so the initial target level should be set above zero. It seems to me that a modest amount of permanent inflation is a small price to pay for significantly reducing the chances of repeating the catastrophic events of the 
early 1930s.

The second lesson for central bankers concerns the functioning of the lender of last resort for the short-term stabilization of the financial system. Effective operation of the lender of last resort is the best method for doing this. There is absolutely no reason that we should ever face a systemic collapse of the banking system of the type seen in the early 1930 s.

Two episodes in the recent financial history of the United States suggest to me that the most important aspects of this lesson have been learned. I have in mind the response to the stock market decline of October 1987 and the collapse of the Savings and Loan industry beginning around the same time. A stock market crash puts the entire financial system at risk for a very short period of time, as some individuals are inevitably bankrupted and cannot make payments on debts that are immediately due. In October of 1987, the Federal Reserve's reaction was to offer banks large amounts of discount loans to enable them to make loans to securities dealers that faced immediate liquidity problems. This is exactly what the lender of last resort should do, and it worked.

The second success was the fact that the Savings and Loans collapse was neutralized. While the difficulties virtually wiped out the Savings and Loan industry, the financial system continued to function and remained sound. The method for containment of the problem was the deposit insurance system. Deposits in Savings and Loans were insured, and while the insurance system itself was bankrupted, the insurance guarantees were honored by the U.S. government through the issuance of Treasury securities. It is clear to me that the ultimate guarantor of these transactions was the Federal Reserve acting again in its capacity as lender of last resort.

The lessons for the construction of financial institutions clearly overlap those for policymakers. I believe the most important involves deposit insurance. While deposit insurance has clear costs in that it cuts the link between a bank's depositors and it asset allocation decisions, it has one extremely important benefit. Since the central bank is the ultimate guarantor of the insurance system, it removes any element of 
discretion about the behavior of policymakers during a pending financial collapse. Beyond this, it is clear that regulatory structures need to be in place to assure that market participants receive the as much information as possible about the riskiness of different financial instruments.

Finally, I come to the international lessons. There are two. First, there is the failure of the interwar gold standard. From this we should have learned about the difficulty in establishing well-functioning institutions to maintain fixed-exchange rates, and the implications of this type of system for the international transmission of business cycles. While I believe that we have learned the lesson, it has taken quite a long time. Second, we have learned that deflation affects international trade through its impact on the real value of tariffs. This simple lesson is yet another reason to fear deflation.

We have clearly come a long way in our understanding of the Depression, but I do not believe we are quite finished. There are still some remaining mysteries. I will close by listing two, each of which comes from a comparison of the recession of 1920-22 with the Great Depression. First, it is my opinion that our understanding the impact of deflation is not quite complete. The logical difficulty is that the earlier period suffered from a more rapid, but nearly as extreme, deflation, but the result was a sharp and quick recession. This suggests that the duration of the deflation is important. But the debt-deflation hypothesis would actually predict that shorter, sharp deflations should be worse, not better. Why was there no Depression in 1922 ?

Related to this same point is that apparent change in the nature of the wagesetting process between 1920 and 1930. Here the point is that real wages seem to have been much less flexible during the Depression than immediately following the end of WWI. Why was this? Without a full understanding of reason for the slow adjustment of aggregate supply during this period we will not be sure that we have learned all that we can. 


\section{References}

Bernanke, Ben S. 1983. 'Non-monetary Effects of the Financial Crisis in the Propagation of the Great Depression.' American Economic Review 73, 257-76.

, 1993. 'The World on a Cross of Gold: A Review of 'Golden Fetters: The Gold Standard and the Great. Depression, 1919-1939,' Journal of Monetary Economics April, $\underline{31}$, 251-267.

, 1995. 'The Macroeconomics of the Great Depression: A Comparative Approach,' Journal of Money, Credit and Banking February, 27, 1-28.

and Gertler, Mark, 1989 'Agency Costs, Net Worth, and Business Fluctuations,' American Economic Review, March, 79, 14-31.

and _. 1990. 'Financial Fragility and Economic Performance.' Quarterly Journal of Economics 105: 87-114.

and James, Harold. 1991. 'The Gold Standard, Deflation and Financial Crisis in the Great Depression: An International Comparison.' In Financial Markets and Financial Crises, ed. R. Glenn Hubbard, Chicago, Ill.: University of Chicago Press for NBER, 33-68.

Bierman, H. 1991. The Great Myths of 1929 and the Lessons to be Learned. New York: Greenwood Press.

Board of Governors of the Federal Reserve, 1929. Federal Reserve Bulletin 15: 93-94.

Calvo, Guillermo A., 1985. 'Temporary Stabilization Policy,' mimeo, Department of Economics, Columbia University, August.

, 1986. 'Temporary Stabilization: Predetermined Exchange Rates,' Journal of Political Economy December, 94, 1319-1329.

Cecchetti, Stephen G., 1988a. 'Deflation and the Great Depression,' mimeo., Department of Economics, Ohio State University, March.

, 1988b, 'The Case of the Negative Nominal Interest Rates: New Estimates

of the Term Structure of Interest Rates During the Great Depression,' Journal of Political Economy, December, $\underline{96}$ 1111-1141.

1992a. 'Prices During the Great Depression: Was the Deflation of 1930-32 Really Unanticipated?' American Economic Review, March, 92, 141-156.

, 1992b. 'The Stock Market Crash of 1929,' in Peter Newman, Murray Milgate and John Eatwell, eds. The New Palgrave Dictionary of Money and Finance, London: Macmillan, Ltd. 
and Karras, G. 1994. 'Sources of Output Fluctuations During the Interwar Period: Further Evidence on the Causes of the Great Depression,' Review of Economics and Statistics, February, 70, 80-102

Choudhri, Ehsan U. and Levis A. Kochin, 1980. 'The Exchange Rate and the International Transmission of Business Cycle Disturbances: Evidence from the Great Depression,' Journal of Money, Credit and Banking, November, $\underline{12}$, 565-574.

Crucini, Mario J., 1994, 'Sources of Variation in Real Tariff Rates: the United States, 1900 to 1940,' American Economic Review, June, 84 732-743.

and James Kahn, 1996. 'Tariffs and Aggregate Economic Activity: Lessons from the Great, Depression,' Journal of Monetary Economics, December, 38 , 427 468 .

Dominguez, Kathryn M., Fair, Ray C. and Shapiro, Matthew D., 1988. 'Forecasting the Depression: Harvard versus Yale.' American Economic Review, September, 78 , $595-612$.

Eichengreen, Barry. Golden Fetters: The Gold Standard and the Great. Depression, 1919-1939. Oxford University Press: New York, 1992.

Fisher, I. 1930. The Stock Market Crash and After. New York: Macmillan.

1933. 'The Debt-Deflation Theory of the Great Depression.' Econometrica, October, $1337-357$.

Friedman, M. and Schwartz, A. 1963. A Monetary History of the United States, 1867-1960. Princeton: Princeton University Press.

Galbraith, J. K. 1954. The Great Crash of 1929. Boston: Houghton Mifflin.

Gordon, Robert J. and James A. Wilcox, 'Monetarist Interpretations of the Great Depression: An Evaluation and Critique,' in Karl Brunner, ed., The Great Depression Revisited. Boston: Martinus Nijhoff, 1981.

Hamilton, James D. 1987. 'Monetary Factors in the Great Depression,' Journal of Monetary Economics March, 19 145-169.

, 1988. 'The Role of the International Gold Standard in Propagating the Great Depression,' Contemporary Policy Issues, April, 6, 67-89.

1992. 'Was the Deflation During the Great Depression Anticipated? Evidence from the Commodity Futures Market.' American Economic Review, March, 92, $157-178$.

Hoover, H. 1952. The Memoirs of Herbert, Hoover. New York: Macmillan.

Meltzer, Allan H., 'Monetary and Other Explanations of the Start of the Great Depression,' Journal of Monetary Economics 2: 458-471. 
Mishkin, F. S. 1978. 'The Household Balance Sheet and the Great Depression.' Journal of Economic History 37: 918-937.

Nelson, Daniel B., 'Was the Deflation of 1929-30 Anticipated? The Monetary Regime as Viewed by the Business Press,' in Ransom, Roger L., ed., Research in Economic History, Volume 13, Greenwich, Conn.: JAI Press, 1991, 1-65.

Romer, C. D. 1990. 'The Great Crash and the Onset of the Great Depression,' Quarterly Journal of Economics 105: 597-625.

Temin, P. 1976. Did Monetary Forces Cause the Great Depression? New York: W.W. Norton.

1989. Lessons from the Great Depression. Cambridge, Mass.: M.I.T. Press. 